\title{
Sustainability in the professional accounting and finance curriculum: an exploration
}

\begin{abstract}
Purpose: Whereas the integration of sustainability into business schools has received increasing attention in recent years, the debate continues to be generic rather than recognising the peculiarities of the more quantitative sub disciplines such as accounting and finance which may of course be intimately linked to professional standards. The purpose of this paper, therefore, is to examine the extent to which sustainability is integrated into accounting and finance curricula in business schools, how, and to understand some of the challenges of doing so.

Design/methodology/approach: This paper presents the findings from a systematic form of literature review which draws on the previous literature about how sustainability is embedded into business school curricula and the challenges in doing so. A particular focus is placed on how the ways in which sustainability is integrated into accounting and finance curricula in business schools.
\end{abstract}

Findings: The paper demonstrates that accounting and finance lags behind other management disciplines in embedding sustainability and that institutional commitment is oftentimes a strong imperative for effective integration of sustainability.

Practical implications: This paper is a call to practitioners and researchers alike to explore new ways of integrating sustainability in the accounting and finance curricula, including working across boundaries to provide learning opportunities for future accountants, financial managers, and generalist managers.

Originality/value: The paper offers an original analysis and synthesis of the literature in the context of the accounting and finance curricula in business schools, and proposed a conceptual framework to further develop sustainability education in the context of business schools. 


\section{Introduction}

The corporate scandals at the beginning of the millennium and the global financial crisis in 2008 have highlighted the importance of considering sustainability issues in business (Wall, 2018). Businesses are beginning to accept their social responsibility through proactive approaches to maximizing their net social contribution, embracing opportunities and managing risks resulting from their economic, environmental and social impacts (Barber et. al, 2014). 95\% of the Global 250 issue sustainability reports and the most widely adopted framework has been the GRI Sustainability Reporting Framework (Ernst and Young, 2013). In particular, sustainable development is described as 'development that meets the needs of the present without compromising the ability of future generations to meet their own needs' (Our Common Future, The World Commission on Environment and Development 1987, p. 43), and therefore includes social, environmental, governance and economic performance (Hommel et al, 2012; Painter-Morland, 2016).

According to Ernst and Young (2013) and PricewaterhouseCoopers (2014), sustainability disclosure can foster investor confidence, improve access to capital and is used by analysts in determining firm valuations. The evolving impact of non-financial information is demonstrated by the fact that "implied" intangible asset value (the difference between a company's market value and book value) comprises $84 \%$ of total market value of the S\&P 500, as compared to 32\% 30 years ago (PwC, 2016). According to PwC’s 2016 Global Investor Survey, over $60 \%$ of investors agree that business success in the 21 st century will be redefined by more than financial profit. In a related metric, 84\% of CEO's in PwC's 2016 Global CEO Survey believe their companies are expected to address wider stakeholder needs.

These are stark statistics but, has the business school curriculum maintained relevance with these developments in business? How relevant is the curriculum to the needs of business in the $21^{\text {st }}$ century? Do business schools talk the talk of sustainability education, and do they walk the talk? How do they talk and walk? To what extent has sustainability been integrated into business school curricula and which approaches are being used? What challenges are business schools facing in the integration process? These are the questions and issues that business schools have to reckon with as they seek to educate business professionals and maintain their relevance in the $21^{\text {st }}$ century, especially in relation to the wider sustainability movements in corporate life (Wall and Jarvis, 2015; Wall, 2017; Wall et al, 2017a; Wall, 2018, forthcoming).

Business schools have been criticised for not responding effectively to the sustainability agenda and for not engaging business leaders on how to strengthen the role of businesses in society (Hommel et.al. 2012; Wall et al 2017c). The criticism has ranged from the generation and treatment of management theory (Ghoshal, 2005), their failure to prepare professionals for the future (Cornuel, 2007; Muff, 2012), and to their failure to respond to societal issues such as sustainability (Cornuel and Hommel, 2015, Snelson et.al. 2016; Wall et al, 2017a). Recent debates have highlighted the need to embed sustainability into the curriculum of business schools (Hommel and Thomas, 2014; Hommel et.al.2012). SnelsonPowell et.al. (2016) argue that although business schools espouse through their policies that they are incorporating sustainability education into their curriculum, in practice many are not. The view today is that management education needs transformation to deal with the crises of responsibility and sustainability (Sharma, 2017). Equally, and perhaps ironically, what contribution have professional accounting bodies made to align themselves with business with regards to sustainability education? Research findings suggest that accounting professionals are rarely involved in sustainability initiatives, but are involved in strategic integration (Ballou et.al, 2012). 
This article seeks to further this debate by examining the extant literature in terms of: the extent to which sustainability is integrated into the accounting and finance curriculum, how it is integrated, the challenges of integrating it, and the relative effectiveness of the various manifestations (Rusinko, 2010). In this way, this article responds to calls for further research into the relative effectiveness of different approaches to embedding sustainability in the curriculum and course-focused research (Painter-Morland et.al., 2016). The rest of the article is organised as follows. The next section examines the extant literature in business and management in relation to the manifestations of how sustainability is integrated and the nature of obstacles faced by business schools in integrating sustainability. This provides the conceptual framework which is then deployed in relation to the systematic approach used as the substantive method in this article. This is then followed by a discussion of the findings in relation to the accounting and finance curricula. The paper concludes with a discussion of the implications, limitations, and future directions of research in this area.

\section{Sustainability in the business school curriculum}

There has been an increase in the number of business schools externally signalling their integration of sustainability into the curricula (Rasche et.al. 2013). However, this rhetoric may not have been matched with internal implementation because of internal and external obstacles (Snelson-Powell, 2016). This decoupling, where activities are signalled externally but not internally implemented may result from business schools' emphasis on prestige and reputation which focus on market measures such as graduate salaries and value for money (Akrivou and Bradbury-Huang, 2015; Wall and Perrin, 2015).

These measures are not consistent with social responsibility (Rasche and Gilbert, 2015). Some researchers have argued to the contrary though, contending that prestige is associated with close coupling of signalling and internal implementation (Snelson-Powell et.al., 2016). What also inhibits the promotion of sustainability education is that faculty reward systems do not sufficiently recognise sustainability expertise and this impacts faculty commitment to research and development in this area (Rusinko, 2010; Hommel et.al., 2012). Faculty resistance may also stem from the fact that widely accepted research metrics such as journal rankings and impact factors do not sufficiently recognise sustainability research (Hommel et.al., 2012; Wall et al 2017a). Furthermore, sustainability is a subject that is related to ethics and some academics believe that ethics (moral right or wrong) cannot be taught (Rasche et.al. 2013).

Other strategic and organisational factors that have been identified as determinants in whether business schools decouple or tightly couple their sustainability policy from practice are organizational size, financial resources, expertise, and prestige (Bromley \& Powell, 2012; Moon \& Orlitzy, 2011; Murphy, Sharma \& Moon, 2012; Rasche \& Gilbert, 2015; Gilbert, 2015; Snelson-Powell et.al, 2016). Prior research has emphasised the need to integrate sustainability both in management education and across the business school (Rusinko, 2010), and more recent empirical work stress the importance of institutional integration in successful integration of sustainability into the curriculum (Painter-Morland et al 2016). Importantly, it also appears that there is a positive link between successful implementation of sustainability integration with investment in faculty with expert knowledge and encouraging sustainability as a research theme (Snelson-Powell et.al., 2016; Moon \& Orlitzky, 2011; Murphy et.al, 2012; Bromley \& Powell, 2012). 


\section{Challenges in integrating sustainability}

There are three main challenges to integrating sustainability in the literature: institutional, pedagogical, and subject-based. In terms of institutional challenges, although there are individuals in business schools who may have the passion and incentive to create and champion new sustainability practices, they may lack the power to influence institutional changes necessary for effective embedding of these practices (Wall et al 2017b). On the other hand, dominant actors within institutions may have the power, but not the motivation (Maguire, 2007, Painter-Morland et.al. 2016). This suggests that it will be important to locate individuals who have both (Barber et. al, 2014). However, there is also a view that sustainability is most effectively integrated into business curricula through a combination of both bottom-up and top-down efforts (Rusinko, 2010).

An overriding issue to consider is the extent to which business schools themselves are being run in line with the values and beliefs of sustainability (Wall and Jarvis 2015; Wall et al 2018, forthcoming). Faculty cannot teach what is not being practised in their institutions, and the nature of the relationship between executive and boards in business schools needs to be addressed (Akrivou and Bradbury-Huang, 2015). Similarly, if faculty are treated as a commodity rather than autonomous agents of change, it is difficult to create a climate and culture in which they themselves are able to develop and deliver curriculum to address sustainability issues. It is likely that faculty members are influenced and shaped by institutional commitments to social, environmental, governance and economic performance issues in teaching, research and HR policies (Painter-Morland et al, 2016). Moreover, business schools are being operated more as a business with an emphasis on profit with performance measures that are indicator driven, which has seemingly kept sustainability at the periphery of institutional strategy and operations (Cornuel and Hommel, 2015).

In terms of pedagogical challenges, the increase in part-time and online provision (which some argue is unsuitable for sustainability education) and the standardisation of educational provision combined with a focus on ranking-related performance indicators (which are also inconsistent with sustainability education) has also stifled the integration process (Cornuel and Hommel, 2015). As business schools strive towards entrepreneurship and a profit model, they have standardised programmes modules to improve efficiencies, with more schools offering shared modules. The drive towards entrepreneurship also seems to reinforce the short-term transactional profit motive which is inconsistent with the values of sustainability (Wall and Perrin 2015).

There is a view that sustainability education is more suited to full-time delivery as students need to engage with dilemmas that are experienced in real life (Cornuel and Hommel, 2015). A shift to a sustainable business paradigm is made easier when educational systems provide students with abilities to live their own 'good lives' and allow them to have a better organisational vision that will foster sustainable business practices. The role of education should be to equip learners to make the decisions in an intelligent way and recognise for themselves that simply justifying decisions on the basis of shareholders' wealth maximisation is inadequate. This is achieved when students engage with each other and with faculty and are exposed to different arguments without restriction so that they make intelligent personal choice and improve their ethical sensitivity (Kelly and Alum, 2009; Dmochowski and Garofalo, 2016; Savelyeva and McKenna, 2011; Wiek and Xiong, 2014; Wall et al 2018, forthcoming).

In terms of subject-based challenges, other potential barriers to integration are students who view higher education degrees as commodities and do not sufficiently value sustainability education (Cornuel \& Hommel, 2015; Wall 2016a; Wall 2016b; Wall et al 2017b). Some students base their application decisions on business school rankings that do 
not include sustainability (Wall and Perrin 2015), and as a result, the integration of sustainability into the curriculum is rarely rewarded with an increase in application numbers. Similarly, business students favour high rewarding careers in investment banking and consultancy and seek to acquire relevant skills in schools that enhance their chances of internship or career in these careers (Morgeson and Nahrgang, 2008). Indeed there has been a significant growth in neoclassical economics and modern finance teaching in most areas of business school teaching and research (Augier and March, 2011; Colby et al., 2011; Wall and Jarvis, 2015). As such, there has been a proliferation of courses such as financial mathematics, quantitative engineering, investment management, all based on modern finance. Most business school graduates are motivated by the potential of significant monetary bonuses from the production of short-term transactional profits in investment banking and consultancy. Business schools have not been able to instil an alternative mind-set in students who then graduate to take up positions in business and finance.

\section{Approaches to integrating sustainability}

One of the most widespread frameworks for understanding how sustainability is integrated in business school curriculum is that proposed by Painter-Morland et al (2016). This matrix is based on both and is consolidated with Rusinko (2010) and Godemann (2011)'s matrices and builds on prior research on the subject (Sammalisto \& Lindhqvist, 2008; Lozano,2006; Ahren, 2009; Moffat, 1988; Christensen te.al.,2007; Tilbury et.al., 2004; Kuh, 1995). The consolidated matrix has five curriculum approaches and integrates co-curricular activities as they both help students to develop self-awareness, reflective thoughts and decision-making that is consistent with education for sustainability and sustainable development (Rusinko, 2010). Co-curricular activities can form a hidden curriculum that facilitates students' practical learning and improve their ethical sensitivity (Borges et.al., 2017). These are summarised in Figure 1 below.

The Painter-Morland (2016) matrix is also consistent with the three approaches used by business schools to respond to the challenge of teaching sustainability. The first approach is educating students about sustainability as a distinct unit of knowledge. This involves designing new courses that are separate from existing offerings and are just bolted on to the existing curriculum (Sterling, 2004; Rusinko, 2010; Sterling, 2013; Snelson-Powell et.al, 2016). This bolt-on approach is intended to teach students about sustainability in isolation rather than produce change in subsequent behaviour or decision making (Snelson-Powell et.al, 2016). The second approach is education for sustainability which involves building sustainability into the whole curriculum and which potentially develops a deeper engagement with sustainability. This is likely to produce change that promotes green behaviour (Rusinko, 2010; Snelson-Powell et.al, 2016). The third approach is capacity building (Rusinko, 2010), which transforms both the curriculum and the institution and enables students to adopt skills for sustainability (Rusinko, 2010).

The holistic approach offered in the matrix is also consistent with the key outcome of the discussion featured in a special issue in the Journal of Management Education in 2009 on the topic, "Greening and Sustainability Across the Management Curriculum”. A key outcome of the discussion was that business schools needed to consider organisational, strategic and operational issues when changing the curriculum to integrate sustainability (Rusinko, 2010; Snelson-Powell et al, 2016). It is also consistent with other models that consider the extent to which sustainability is integrated (Sterling, 2013) as well as the resources required for a different level of integration (Moon \& Orlitzky, 2011).

As pointed out before in this article, integration of sustainability into the curriculum is most effective if there is commitment from leadership (Lee \& Schaltegger, 2014), and there 
are a range of institutional factors that are key to successful integration of sustainability into the curriculum (Burchell, 2015). These factors include having enabling leadership, building relationships with non-academic stakeholders (e.g. business communities) and investing in faculty development (Akrivou and Bradbury-Huang, 2015; Painter-Morland et.al., 2016, Cornuel and Hommel, 2015). A summary of the relative advantages and disadvantages of the various approaches, along some of the organisational conditions which support each approach, are presented in Table 1 below.

Figure 1. Approaches to integrating sustainability into Business School curriculum. Adapted from Rusinko (2010), Painter-Morland et.al. (2016), and Wall et al (2017b)

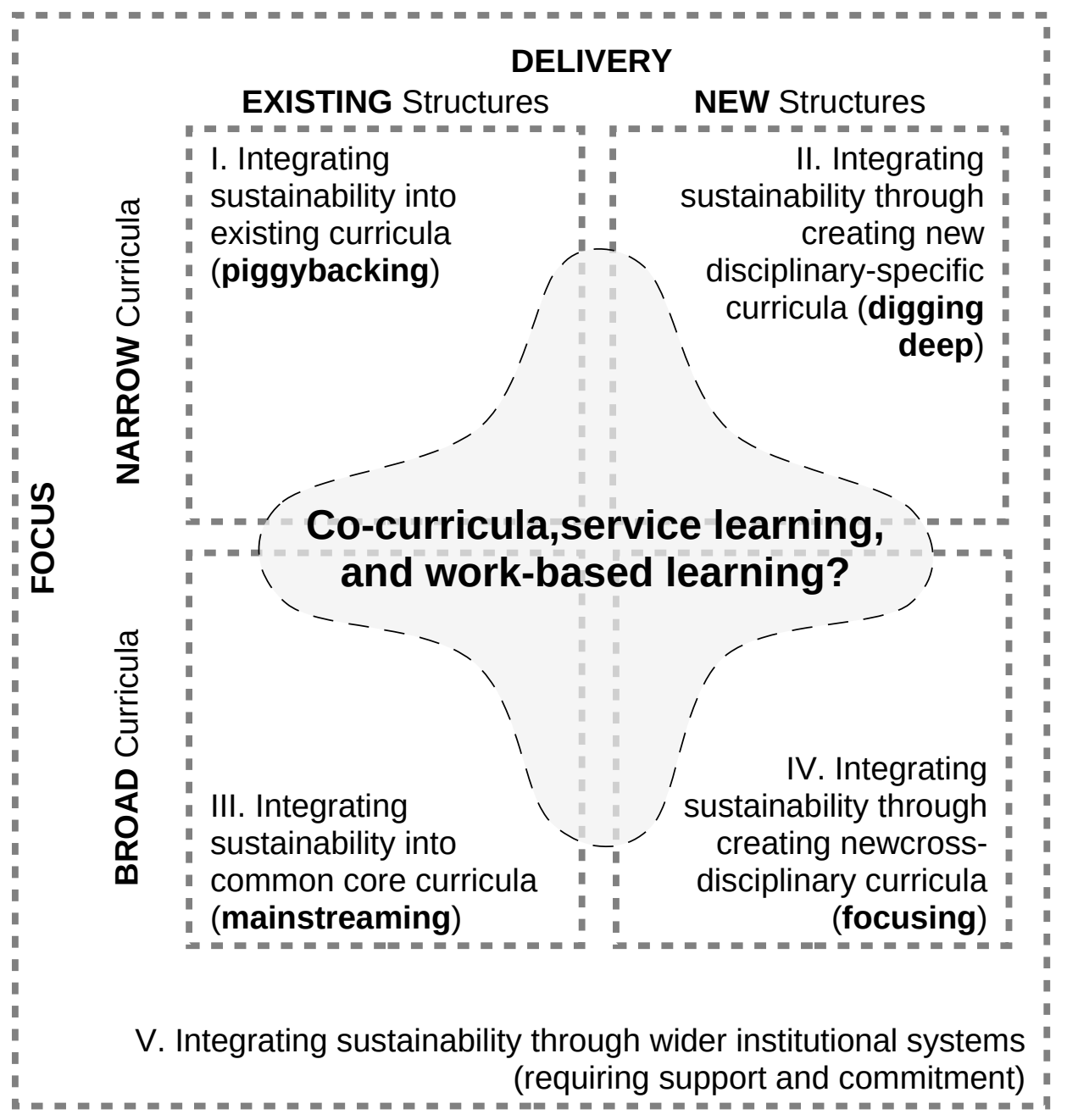


Table 1: Alternative approaches and related systems conditions supporting implementation, adapted from Rusinko (2010), Painter-Morland et.al. (2016), Wall \& Hindley (2018, forthcoming)

\begin{tabular}{|c|c|c|c|}
\hline Approach & Relative advantages & Relative disadvantages & $\begin{array}{c}\text { Operational conditions within the } \\
\text { system }\end{array}$ \\
\hline I. & $\begin{array}{l}\text { Can potentially reach many students with } \\
\text { minimal resources, and operationally } \\
\text { simple compared to other options. }\end{array}$ & $\begin{array}{l}\text { Often very narrow and limited } \\
\text { implementation which is positioned as } \\
\text { subservient to other conceptual and } \\
\text { practical knowledge in the curricula, and } \\
\text { may not enable progressively deeper forms } \\
\text { of exposure or learning over a programme. }\end{array}$ & $\begin{array}{l}\text { When there are limited resources to } \\
\text { operationalise sustainability; when } \\
\text { there are driven individuals; when } \\
\text { exploring or experimenting with } \\
\text { approach and developing staff } \\
\text { capabilities and/or interest. }\end{array}$ \\
\hline II. & $\begin{array}{l}\text { Can potentially allow for greater } \\
\text { specialisation, and greater opportunity } \\
\text { for creating a more consistent approach } \\
\text { across curricula. }\end{array}$ & $\begin{array}{l}\text { Often requires more resources than above, } \\
\text { and although it might make sustainability } \\
\text { more distinctive, it might still position it as } \\
\text { an optional add-on and therefore } \\
\text { subservient. }\end{array}$ & $\begin{array}{l}\text { When there are resources available to } \\
\text { establish and maintain the curricula, } \\
\text { and when there is a need to highlight } \\
\text { the sustainability content of a } \\
\text { particular area. }\end{array}$ \\
\hline III. & $\begin{array}{l}\text { Can potentially reach a large number of } \\
\text { students, and enables subject and sub- } \\
\text { disciplinary boundaries to be crossed } \\
\text { more easily which is useful for bigger } \\
\text { picture and gradual-immersion } \\
\text { perspectives and approaches to learning. }\end{array}$ & $\begin{array}{l}\text { Often requires major resources to establish } \\
\text { and coordinate across subject or even sub- } \\
\text { disciplinary boundaries. }\end{array}$ & $\begin{array}{l}\text { When resources are available to lead, } \\
\text { coordinate and maintain } \\
\text { implementation across boundaries, } \\
\text { when sustainability is a an important } \\
\text { focus or priority across a wider } \\
\text { organisational structure, and when } \\
\text { there is an expertise in sustainability. }\end{array}$ \\
\hline IV. & $\begin{array}{l}\text { Can potentially reach a large number of } \\
\text { students, enables the possibility of } \\
\text { promoting a strong and distinctive image } \\
\text { and brand, and can facilitate a gradual } \\
\text { immersion approach to learning. }\end{array}$ & $\begin{array}{l}\text { Often requires one of the highest levels of } \\
\text { resources out of all options (including } \\
\text { leadership, coordination, and } \\
\text { maintenance). }\end{array}$ & $\begin{array}{l}\text { When sustainability is a strategic goal } \\
\text { across the wider business and } \\
\text { management subject structure, and } \\
\text { when there is expertise in } \\
\text { sustainability. }\end{array}$ \\
\hline
\end{tabular}




\begin{tabular}{|l|l|l|l|}
\hline V. & $\begin{array}{l}\text { Can potentially develop wider scale } \\
\text { capacities across staff groups, and can } \\
\text { support the development of broader } \\
\text { levels of consistency across the broader } \\
\text { organisational structure. }\end{array}$ & $\begin{array}{l}\text { Often requires the highest level of } \\
\text { resources out of all options (including } \\
\text { leadership, coordination, and maintenance } \\
\text { at the institutional level). }\end{array}$ & $\begin{array}{l}\text { When sustainability is a strategic goal } \\
\text { across the wider institutional structure, } \\
\text { and when there is expertise in } \\
\text { sustainability (whether localised or } \\
\text { distributed). }\end{array}$ \\
\hline $\begin{array}{l}\text { Co- } \\
\text { curricular } \\
\text { service } \\
\text { and work- } \\
\text { based } \\
\text { learning }\end{array}$ & $\begin{array}{l}\text { Can potentially initiate and promote } \\
\text { boundary-crossing perspectives and } \\
\text { collaborations, including community and } \\
\text { student initiated sustainability activity. }\end{array}$ & $\begin{array}{l}\text { Often requires additional resource } \\
\text { demands, and can have a very narrow and } \\
\text { limited implementation which is } \\
\text { positioned as subservient to other } \\
\text { conceptual and practical knowledge in the } \\
\text { curricula. }\end{array}$ & $\begin{array}{l}\text { When there is a need to increase or } \\
\text { enhance student and/or wider } \\
\text { community engagement in } \\
\text { sustainability, when there is staff } \\
\text { commitment, drive and capability to } \\
\text { support collaborative activity. }\end{array}$ \\
\hline
\end{tabular}




\section{Sustainability in the accounting and finance curriculum}

Compared to many disciplines in the social and administrative sciences, the greening of the curriculum in accounting and finance is a recent phenomenon (Marx \& Watt, 2015).

Sustainability adoption in the accounting and finance curricula is a critical issue for improved business education, given the recent business failures and financial crises that seriously affected economies around the world (de Lange 2013). Many of these failures and crises have had their roots in accounting and/or finance. The financial crisis of 2008 was closely associated with excessive risk taking and greed in the financial markets from the securitisation of sub-prime debt to the creation of collateral debt obligation and other credit products (Bernstein, 2008; Bloom, 2013; Wallison, 2011; Deepak, 2010). The Enron collapse was instigated by the overstatement of assets and revenue. As such, it is important that the accounting and finance curricula integrate sustainability effectively as they produce future business leaders in financial markets, and these leaders should understand the role of business in society. One of the biggest challenges in sustainability integration in practice is the operationalisation of sustainability measures and outcomes (Sammalisto \& Lindhqvist, 2008; Rusinko, 2010), and relevant research in accounting and finance curricula can play a major role in the development of these measurement tools.

Internal resistance from faculty members in accounting, finance and economics may also contribute to the decoupling because these disciplines are based on theoretical assumptions which are not consistent with sustainability. This may explain why the integration of sustainability in accounting and finance curricula lags behind other disciplines (de Lange 2013), and echoes Ghoshal's (2005) criticism of the decontextualized and apparently stable management theory taught in business schools. There are some arguments, however, that there now exists a body of knowledge in accounting and finance that module content consistent with sustainability can be based on (Painter-Morland, 2016). What cannot be denied though is the fact that the theoretical underpinning of finance and economics disciplines is still largely based on the assumption of investor primacy, efficient markets and rational expectations. This article, however, seeks to examine this in more depth and the next section discusses the substantive method of this article.

\section{Method}

To assess the appropriateness of the Paint-Morland et al (2016) matrix, this article set out to examine the literature for the approaches used to integrate sustainability in the business and management curriculum with a particular focus on accounting and finance curricula from the year 2010 to date. Specifically, the goal was to identify sustainability integration activities by business schools and assess if the approaches used were consistent with the five broad categories established by Painter-Morland (2016) (see Figure 1). The studies selected were from around the world because of the global challenges facing business schools with regards to sustainability (Muff, 2012; Hommel et.al., 2012; Snelson-Powell, 2016; Cornuel and Hommel, 2014).

Initially, a web-based literature search was conducted using such search phrases as "sustainability in higher education”, "integrating sustainability in the curriculum”, "embedding sustainability into the accounting and finance curriculum”. The search included grey literature, using reference lists and citation searching from published papers. Studies selected were (1) published in English, (2) were specifically on integrating sustainability in the curriculum, (3) both quantitative and qualitative studies, (4) were conducted in a business school and (5) were done after 2010. These are summarised in Table 2 below. 
Although preference was given to studies in ranked journals, some studies from nonacademic publications were included because of the relevance of the paper to the research focus. A view was taken that sustainability as a field of study is still emerging and may be regarded as niche and therefore does not feature significantly in highly ranked journals. The selected studies were found to generally fall into the five broad categories listed above and so were grouped accordingly. Where information was available, the curriculum area of integration and mode of delivery were detailed (see Table 4 in appendix). The curriculum areas were classified as either accounting/finance or business. A summary of the results is outlined in Table 3 below.

The search of the databases retrieved 210 records and following screening, these were distilled to 35 academic records. A total of 48 instances of integration were found, however: it was not clear in 3 studies whether approach 1 or 2 were used, it was not clear in 7 studies whether approach 4 or 5 were used, it was not clear in 2 studies whether approach 2 or 4 were used, and it was not clear in 1 study whether approach 3 or 4 were used. As a result, 13 studies were double-counted.

Table 2. Inclusion and exclusion criteria

\begin{tabular}{|l|l|l|}
\hline & Inclusion Criteria & Exclusion criteria \\
\hline Study design & $\begin{array}{l}\text { Cross-sectional studies, longitudinal } \\
\text { studies, case reports }\end{array}$ & $\begin{array}{l}\text { Literature review, } \\
\text { methodological papers }\end{array}$ \\
\hline Population & Business schools- worldwide & $\begin{array}{l}\text { Non-academic setting/work } \\
\text { samples }\end{array}$ \\
\hline Integration & Any approach & Non-integration intervention \\
\hline
\end{tabular}

Table 3. Summary of responses by integration strategy

\begin{tabular}{|c|l|l|}
\hline Approach & Number of studies & Curriculum area \\
\hline I. & 8 & Accounting/Finance (6); Business (2) \\
\hline II. & 11 & Accounting/ Finance (5); Business (6) \\
\hline III. & 2 & Business \\
\hline IV. & 18 & Accounting/finance(2); Business(16) \\
\hline V. & 7 & Business \\
\hline Co-curricular activities & 2 & \\
\hline Total & 48 & \\
\hline
\end{tabular}

\section{Discussion}

The purpose of this study was to examine the extent to which accounting and finance curricula were integrating sustainability into their curricula, and how, using the approaches outlined by Painter-Morland et. al. (2016). In general, the studies analysed fell into the five broad approaches, and out of the 35 articles found, 13 of the studies used more than one approach. As demonstrated by Rusinko (2010), approaches can be used in any order and two or more approaches can be implemented simultaneously. As such there are studies where business schools seemed to be using more than one approach.

Overall, the studies indicate that integration is more effective when leadership commitment exists. This is when approaches 4 and 5 are used, where more students are exposed to sustainability and new compulsory modules and new programmes are developed. No study explicitly indicates that approach 5 is being used. This approach requires leadership 
commitment, engagement with non-academic stakeholders and investment in faculty development. In 7 studies, there is evidence that sustainability is a strategic imperative. The schools where these studies are done are all PRME signatories. Although there seems to be a strong awareness of the importance of leadership commitment in these schools, there is no clear evidence of faculty development support or engagement with external stakeholders. These findings are consistent with the survey results from the study by Painter-Morland et.al. (2016).

Contrary to Painter-Morland et al's (2016) survey results however, the studies found in this study indicate that most schools which are integrating sustainability into their curriculum have leadership commitment and are members of PRME. However, this could simply be because the schools that report their progress in integrating sustainability are the ones that have made a strategic commitment to do so.

From the studies selected, it seems that sustainability is being integrated into the accounting and finance curricula mainly using approaches 1 (when business schools integrate aspects of sustainability into their existing modules) and 2 (when stand-alone sustainability modules are added to the curriculum). These approaches are narrow focussed and do not expose a large number of students to sustainability. They are therefore not as effective as approaches 3 and 4 in improving students' ethical sensitivity.

According to both Rusinko (2010) and Painter-Morland (2016), approaches 1 and 2 are the easiest approaches to use as they either do not need any changes to the curriculum or new modules that are offered are optional. Sustainability is therefore integrated in areas where it is consistent with the existing pedagogy. Indeed, this seems to be the main problem that traditional disciplines like accounting, finance and economics face. The traditional accounting theory is framed by neoclassical micro-economics and a shareholder value perspective and this is not always consistent with sustainability-friendly pedagogy (Ghoshal, 2005). It therefore seems easier for accounting and finance faculty to integrate sustainability in the convenient sections of the curriculum.

In terms of challenges to implementing the integration of sustainability, Muff (2012) has argued that faculty believe the teaching of sustainability in these disciplines causes students to start questioning the theoretical underpinning of existing pedagogy. Similarly, Gray (2013) has also observed in his study that there is lack of relevant literature on sustainability in accounting and finance and that it is difficult to develop relevant resources.

Others provide a more critical perspective such as Gusc \& Veen-Dirks (2016) who observe that sustainability learning is not consistent with traditional learning strategy in accounting. They propose integrating sustainability using active learning through assignment coursework. If approach 2 is used, stand-alone modules can easily be decoupled from the core content in the accounting and finance curricula (Snelson-Powell, 2016). However, as Rusinko (2010) pointed out, this approach can isolate sustainability especially if modules are stand-alone electives. Martinov-Bennie \& Mladenovic (2013) compares approaches 1 and 2 and claim that approach 1 exposes students to a range of ethical issues which helps ethical decision-making but having stand-alone modules improves students' ethical judgement. What seems to be emerging from the above observations is that the method of integrating sustainability will have an impact students' engagement and future decision making (Burga et.al., 2017).

It also appears that approach 3, where sustainability-related issues are integrated into the majority of existing modules across the board, is not being commonly used. Only 2 of the studies selected used this approach. This is also consistent with Painter-Morland et.al. (2016)'s survey findings.

Approach 4 (where a large number of new sustainability-related compulsory modules or new programmes are developed) is dominated by generic business programmes. In one 
study, Dmochowski et al (2015) found that integrating sustainability across the curriculum is facilitated by students who are recruited as research assistants to find areas where sustainability can be incorporated within the curriculum. As a result, faculty students' collaboration takes places. Indeed, Warwick et.al. (2017) explain the importance of students' feedback on initiatives to integrate sustainability.

Schools that have used co-curricular activities to integrate sustainability in the curriculum have expressed the importance of using students as catalysts for change in behaviour and future decision-making (Wall et al 2017b). Borges et al (2017) explain that cocurricular activities enhance learning and form a hidden curriculum that teaches responsible management education.

Beyond the approach to integrating sustainability in the accounting and finance curriculum, there seems to be a link between integration approaches used and schools' organisational and strategic commitment. In schools that have used approach 1, it is individual faculty members that have taken the initiative to change parts of their modules to incorporate sustainability (Gray, 2013). Such a sporadic approach does not necessarily signal the importance of sustainability to students and may be ineffective as the subject of sustainability may be viewed as peripheral (Rusinko, 2010). On the other hand, schools that have used approaches 4 or are moving towards approach 5, have made an organisational and strategic commitment to the change process, which may include resource allocation (Rive et al, 2017; Wersun, 2017; Korb et al, 2017; Cicmil, et al, 2017). As Painter-Morland (2016) point out, it is important to have enabling leadership, to be connected to key constituents and to build capacity for the integration process to succeed. One can therefore suggest that there is a continuum of approaches from approach 1 to approach 5, with approach 1 potentially being associated with having least reach (in terms of number of students) and the least learning impact (in terms of exposure), towards approach 5 having the highest reach and deepest impact. However, at this time, the studies being conducted in this area have not undertaken this analysis and longitudinal studies would be required to explore this.

In addition, there also seems to be a link between approach and the curriculum area.

In accounting and finance curricula, studies have shown that sustainability is being integrated through a narrow discipline specific approach (Lozano, 2006), predominantly utilising approaches 1 and 2. This may be due to the content of these programmes which is based on value maximisation and may be seen to be inconsistent with sustainability. The challenge here appears to be the demonstration that sustainability practices do not destroy value but actually preserve and add value. Indeed the association between sustainability practice or reporting and value creation is still an issue that is being debated in finance research (Jones et al, 2007; Aust, 2013; Prober et.al, 2015; Gómez-Bezares, Przychodzen and Przychodzen, 2016; Seira-Garcia and Zorio, 2013; Carnevale et al, 2012; Ansari et.al, 2015; Van et.al.,2015; Carnevale and Mazzuca, 2012). It appears therefore that more pedagogical research and development work needs to be done to redress this.

\section{Implications, limitations and future directions}

A limitation of this study has been the shortage of studies evaluating the approaches used to integrate sustainability into the curriculum, and there is a need for further systematic research in this area. In particular, longitudinal studies are needed that take into account recent developments including the impact of PRME and the increasing emphasis on sustainability by accreditation bodies such as EQUIS, AMBA, and AACSB. The studies available do not enable concrete conclusions to be reached in relation to assessing the relative effectiveness of the different approaches, particularly of co-curriculum activities (Borges et al, 2017; Korb et al, 2017). It is not possible from the studies to reach a conclusion on whether to integrate 
sustainability into the curriculum using a combination of curriculum and co-curriculum activities or if co-curriculum activities are effective on their own.

It is important in future to assess the relative effectiveness of these approaches through the lens of students and student learning (Warwick et.al., 2017). This also calls for further research that assesses the extent to which students develop the range of values and beliefs to meet the current sustainability challenge, i.e. to act as sustainability change agents (Akrivou and Bradbury-Huang, 2015). A conceptual framework which might help towards this in the context of integrating sustainability into the curriculum is based on a longstanding systems perspective proposed by Biggs (1989, 1992): the presage-process-product model. Presage is concerned with student factors and include students' prior learning or awareness of sustainability issues, their motivation in wanting to be 'responsible citizens' and their ability, and teacher factors, which might include the faculty's own knowledge of sustainability issues and their motivation to integrate sustainability into the curriculum.

Process refers to task processing includes the different learning focussed tasks set to facilitate the learning process, and might include (1) educating students about sustainability which involves designing new courses that are separate from existing offerings and are just bolted on to the existing curriculum (Sterling, 2004; Rusinko, 2010; Sterling, 2013; SnelsonPowell et.al, 2016), (2) education for sustainability which involves building sustainability into the whole curriculum and which potentially develops a deeper engagement with sustainability (Rusinko, 2010; Snelson-Powell et.al, 2016) and (3) capacity building which transforms the both the curriculum and the institution and enables students to adopt skills for sustainability (Rusinko, 2010). The learning activities can either be appropriate and deep or inappropriate and shallow. The product factors are the learning outcomes whose effectiveness can be assessed from the viewpoint of students. Examples are provided in Figure 2 below.

All of these activities take place within the constraints of imposed by the institution, and include resource allocation, leadership involvement and the extent to which sustainability is included in the institution's strategy. There is feed forward and feedback within the system that enables changes to be made to the teaching and learning activities to achieve optimum results. The relationship between specific strategic and organisational characteristics and the approach used to integrate sustainability is another area that needs further research. This is important as it gives schools a tool-box from which to design solutions that are unique to their own circumstances.

Of particular concern is the integration of sustainability into the accounting and finance curriculum. From the studies selected, it seems the greening of the accounting and finance curricula lag those of other business disciplines. An area of further study would be in assessing methods of dealing with the unique challenges in integrating sustainability into accounting and finance curricula. 


\begin{tabular}{|c|c|c|}
\hline $\begin{array}{l}\text { Student (presage): } \\
\text { Explore current } \\
\text { knowledge and } \\
\text { motivations for } \\
\text { sustainability outcomes }\end{array}$ & \multirow{2}{*}{$\begin{array}{l}\text { Deeper } \\
\text { processing over } \\
\text { the duration of } \\
\text { studies } \\
\text { Resources for } \\
\text { development } \\
\text { Number (reach) } \\
\text { of interactions }\end{array}$} & \multirow{2}{*}{ 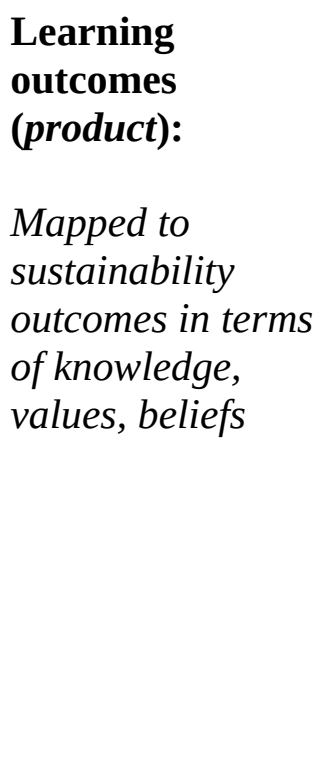 } \\
\hline $\begin{array}{l}\text { Teacher (presage): } \\
\text { Developed in relation to } \\
\text { sustainability outcomes in } \\
\text { terms of knowledge, } \\
\text { values, beliefs over time } \\
\text { Resources for } \\
\text { development } \\
\text { Role models }\end{array}$ & & \\
\hline
\end{tabular}

Figure 2. A proposed conceptual framework in relation to assessing effectiveness of approach (informed by Biggs’s presage-process-product model, 1989, 1992)

\section{Conclusion}

This paper is based on previous research on approaches to integrating sustainability into the curriculum. It utilises a widely utilised matrix of options to examine how sustainability is integrated in business schools as well as the specific accounting and finance curricula within them. This paper argues that the accounting and finance curricula lags behind the other developments made in business schools and calls for more pedagogical research and development to be done to embed sustainability within the curricula. In particular, the paper calls for a more nuanced way of assessing the effectiveness of the various approaches to embedding sustainability into the curricula and proposes a more nuanced conceptual framework to help practitioners and researches to integrate sustainability into their curricula, with a view towards creating organisational leaders of the future. 
Appendix - Table 4 - list of articles found in this study

\begin{tabular}{|c|c|c|c|c|c|c|}
\hline Author and Date & Journal & $\begin{array}{l}\text { Journal } \\
\text { ranking }\end{array}$ & $\begin{array}{l}\text { Approach to } \\
\text { integration }\end{array}$ & Country & Curriculum area & Main findings \\
\hline $\begin{array}{l}\text { Akrivou \& Bradbury- } \\
\text { Hhuang, } 2015\end{array}$ & $\begin{array}{l}\text { Academy of } \\
\text { Management Learning \& } \\
\text { Education }\end{array}$ & 4 & $4 / 5$ & & N/A & $\begin{array}{l}\text { Students should be educated to become integrated } \\
\text { catalysts to meet current sustainability challenges. } \\
\text { Wider organisational structure should also be } \\
\text { organised to develop as catalysts for change. }\end{array}$ \\
\hline $\begin{array}{l}\text { Annan-Diab \& Molinari, } \\
2017 .\end{array}$ & $\begin{array}{l}\text { International Journal of } \\
\text { Management Education }\end{array}$ & 1 & 4 & UK & MBA & $\begin{array}{l}\text { Peer- collaboration by students from different } \\
\text { disciplines advances their understanding of } \\
\text { sustainability issues. }\end{array}$ \\
\hline $\begin{array}{l}\text { Awaysheh \& Bonfiglio, } \\
2017\end{array}$ & $\begin{array}{l}\text { International Journal of } \\
\text { Management Education }\end{array}$ & 1 & 4 & USA & MBA & $\begin{array}{l}\text { Business schools can use experiential learning to } \\
\text { incorporate social entrepreneurship in advancing } \\
\text { sustainability learning. }\end{array}$ \\
\hline Beddewela et.al., 2017 & $\begin{array}{l}\text { International Journal of } \\
\text { Management Education }\end{array}$ & 1 & 4 & UK & various & $\begin{array}{l}\text { Majority of accounting and finance modules did } \\
\text { not have responsible management education } \\
\text { content. Without clear commitment from } \\
\text { leadership there will be inconsistencies in } \\
\text { implementing change. }\end{array}$ \\
\hline Borges (a) et.al.,2017 & $\begin{array}{l}\text { International Journal of } \\
\text { Management Education }\end{array}$ & 1 & N/A & Brazil & & $\begin{array}{l}\text { Student organisations are important in advancing } \\
\text { sustainability agenda. }\end{array}$ \\
\hline Borges et.al.,2017 & $\begin{array}{l}\text { International Journal of } \\
\text { Management Education }\end{array}$ & 1 & N/A & Brazil & & $\begin{array}{l}\text { Co-curricular activities enhance learning and are a } \\
\text { hidden curriculum that teaches responsible } \\
\text { management. }\end{array}$ \\
\hline Botes et.al., 2014 & $\begin{array}{l}\text { Sustainability } \\
\text { Accounting, } \\
\text { Management and Policy } \\
\text { Journal }\end{array}$ & 2 & $2 / 4$ & $\mathrm{NZ}$ & Accounting. & $\begin{array}{l}\text { Offering new modules develop students' } \\
\text { knowledge of sustainability as they have time to } \\
\text { take an interdisciplinary approach. }\end{array}$ \\
\hline Burga et.al., 2017 & $\begin{array}{l}\text { International Journal of } \\
\text { Management Education }\end{array}$ & 1 & 2 & Canada & CSR & $\begin{array}{l}\text { Method of delivery important in impacting } \\
\text { student engagement and future decision making. }\end{array}$ \\
\hline Carreira et.al., 2017 & $\begin{array}{l}\text { International Journal of } \\
\text { Management Education }\end{array}$ & 1 & 4 & Brazil & N/A & $\begin{array}{l}\text { Relevant games in class activities can stimulate } \\
\text { engagement with sustainability issues among } \\
\text { students. }\end{array}$ \\
\hline Cicmil et.al.,2017 & $\begin{array}{l}\text { International Journal of } \\
\text { Management Education }\end{array}$ & 1 & $4 / 5$ & UK & N/A & $\begin{array}{l}\text { Institutional priorities must be aligned with } \\
\text { curriculum development for successful } \\
\text { integration. }\end{array}$ \\
\hline Coulson \& Thomson, 2006 & Accounting Education & 2 & 1 & UK & $\begin{array}{l}\text { Accounting/ } \\
\text { finance. }\end{array}$ & $\begin{array}{l}\text { No institutional changes were made to } \\
\text { accommodate new elective module. Constraints }\end{array}$ \\
\hline
\end{tabular}




\begin{tabular}{|c|c|c|c|c|c|c|}
\hline & & & & & & included more work for the faculty. \\
\hline Dmochowski et.al.,2015 & $\begin{array}{l}\text { International Journal of } \\
\text { Sustainability in Higher } \\
\text { Education }\end{array}$ & NA & 3 & USA & business & $\begin{array}{l}\text { Integrating sustainability across the curriculum } \\
\text { programme, where students are recruited as } \\
\text { research assistants to incorporate sustainability. }\end{array}$ \\
\hline Filho, 2017 & $\begin{array}{l}\text { The International Journal } \\
\text { of Management } \\
\text { Education }\end{array}$ & 1 & 4 & Brazil & N/A & $\begin{array}{l}\text { Transdisciplinary approach encourages research, } \\
\text { provides discussions in the classroom } \\
\text { and stimulates collective knowledge by } \\
\text { integrating students to the corporate world. }\end{array}$ \\
\hline Fisher \& Bonn, 2017 & $\begin{array}{l}\text { Australian Journal of } \\
\text { Environmental } \\
\text { Education }\end{array}$ & NA & 1 & & business & $\begin{array}{l}75 \% \text { of business schools in Australia did not have } \\
\text { a single module in sustainability between } 2009 \\
\text { and } 2014 \text {. }\end{array}$ \\
\hline Gray, 2013 & Accounting Education & 2 & $1 / 2$ & UK & Accounting & $\begin{array}{l}\text { Lack of literature in field, and difficult to develop } \\
\text { relevant resources. }\end{array}$ \\
\hline Greenberg et.al.,2017 & $\begin{array}{l}\text { International Journal of } \\
\text { Management Education }\end{array}$ & 1 & $4 / 5$ & USA & & $\begin{array}{l}\text { Difficulty in changing pedagogy because of } \\
\text { faculty resistance. }\end{array}$ \\
\hline Gusc \& Veen-Dirks, 2016 & $\begin{array}{l}\text { International Journal of } \\
\text { Sustainability in Higher } \\
\text { Education }\end{array}$ & NA & 1 & Netherlands & $\begin{array}{l}\text { Accounting/ } \\
\text { Finance }\end{array}$ & $\begin{array}{l}\text { Sustainability learning not consistent with } \\
\text { traditional learning strategy in accounting, so } \\
\text { introduce active learning through/in assignments. } \\
\text { Lack of relevant resources in accounting apparent. }\end{array}$ \\
\hline Hahn \& Reimsbach, 2014 & $\begin{array}{l}\text { Journal of Global } \\
\text { Responsibility }\end{array}$ & NA & 1 & Germany & accounting & $\begin{array}{l}\text { Students exposed to sustainability coursework; } \\
\text { factor it into valuations. }\end{array}$ \\
\hline Haskin \& Burke, 2016. & $\begin{array}{l}\text { American Journal of } \\
\text { Business Education }\end{array}$ & NA & $1 / 2$ & USA & $\begin{array}{l}\text { Financial } \\
\text { accounting. }\end{array}$ & $\begin{array}{l}\text { Traditional accounting teaching strategy and } \\
\text { pedagogy not consistent with sustainability. } \\
\text { incorporating SASB accounting standards as a } \\
\text { vehicle for teaching accounting improves } \\
\text { students' understanding of sustainability issues. }\end{array}$ \\
\hline Korb et.al.,2017 & $\begin{array}{l}\text { International Journal of } \\
\text { Management Education }\end{array}$ & 1 & $4 / 5$ & Germany & various & $\begin{array}{l}\text { Co-curricular, curricular and trans-disciplinary are } \\
\text { all important in the integration process, as well as } \\
\text { institutional support. }\end{array}$ \\
\hline Lee \& Schaltegger, 2014 & $\begin{array}{l}\text { International Journal of } \\
\text { Sustainability in Higher } \\
\text { Education }\end{array}$ & NA & 5 & Australia & MBA & $\begin{array}{l}\text { Leadership plays an important role in enabling } \\
\text { sustainability transformation of universities, and } \\
\text { links to Mintzberg’s leadership framework. }\end{array}$ \\
\hline $\begin{array}{l}\text { Martinov-Bennie \& } \\
\text { Mladenovic, } 2013\end{array}$ & $\begin{array}{l}\text { Journal of Business } \\
\text { Ethics }\end{array}$ & 3 & $1 / 2$ & Australia & Accounting. & $\begin{array}{l}\text { Piggybacking exposes students to a range of } \\
\text { ethical issues which helps ethical decision- } \\
\text { making, and having a stand-alone module } \\
\text { improves students' ethical judgement. }\end{array}$ \\
\hline Marx \& Watt, 2015 & $\begin{array}{l}\text { South African Journal of } \\
\text { Accounting Research }\end{array}$ & NA & 1 & South Africa & Accounting & $\begin{array}{l}\text { The issue of sustainability in accounting } \\
\text { education is a new theme. }\end{array}$ \\
\hline
\end{tabular}




\begin{tabular}{|c|c|c|c|c|c|c|}
\hline Muff, 2012 & $\begin{array}{l}\text { Journal of Management } \\
\text { Development }\end{array}$ & 1 & $3 / 4$ & Switzerland & business & $\begin{array}{l}\text { Redesigned the whole BA degree programme and } \\
\text { embedded sustainability across the whole } \\
\text { curriculum. Both commitment and challenge from } \\
\text { faculty, including priority clashes. }\end{array}$ \\
\hline Naeem \& Peach, 2011 & $\begin{array}{l}\text { International Journal of } \\
\text { Sustainability in Higher } \\
\text { Education }\end{array}$ & NA & 2 & Asia Pacific & business & $\begin{array}{l}\text { There is insufficient collaboration occurring to } \\
\text { achieve the transformative agenda of education } \\
\text { for sustainable development; need to collaborate } \\
\text { across institutions. }\end{array}$ \\
\hline Ortiz \& Huber-Heim, 2017 & $\begin{array}{l}\text { International Journal of } \\
\text { Management Education }\end{array}$ & 1 & 2 & Austria & & $\begin{array}{l}\text { Collaborative learning with peers and engagement } \\
\text { with external stakeholders could have enhanced } \\
\text { the learning process. }\end{array}$ \\
\hline Perera \& Hewege, 2015 & $\begin{array}{l}\text { International Journal of } \\
\text { Sustainability in Higher } \\
\text { Education }\end{array}$ & NA & 1 & Australia & marketing & $\begin{array}{l}\text { Curriculum development projects aimed at } \\
\text { integrating sustainability education into } \\
\text { international business and marketing curricula are } \\
\text { scarce. }\end{array}$ \\
\hline Rive et.al., 2017 & $\begin{array}{l}\text { International Journal of } \\
\text { Management Education }\end{array}$ & 1 & $4 / 5$ & France & & $\begin{array}{l}\text { Engaging other stakeholders is important in } \\
\text { delivering change, and this was reflected in the } \\
\text { school's strategic focus. }\end{array}$ \\
\hline $\begin{array}{l}\text { Savelyeva \& Mckenna, } \\
2011\end{array}$ & $\begin{array}{l}\text { International Journal of } \\
\text { Sustainability in Higher } \\
\text { Education }\end{array}$ & NA & 2 & World-wide & business & $\begin{array}{l}\text { Uses an interdisciplinary global seminar } \\
\text { approach; discusses sustainability issues with } \\
\text { students from other countries. }\end{array}$ \\
\hline Sisaye, 2013 & $\begin{array}{l}\text { World Journal of } \\
\text { Entrepreneurship, } \\
\text { Management and } \\
\text { Sustainable } \\
\text { Development }\end{array}$ & NA & 4 & USA & accounting & $\begin{array}{l}\text { Compared to many disciplines in the social and } \\
\text { administrative sciences, the greening of the } \\
\text { curriculum in accounting is a recent phenomenon. }\end{array}$ \\
\hline Tyran, 2017 & $\begin{array}{l}\text { International Journal of } \\
\text { Management Education }\end{array}$ & 1 & 2 & USA & & $\begin{array}{l}\text { Giving students an opportunity to collaborate with } \\
\text { people from a variety of disciplines and } \\
\text { backgrounds in a developing country through a } \\
\text { faculty-led international service learning course. }\end{array}$ \\
\hline Warwick et.al., 2017 & $\begin{array}{l}\text { International Journal of } \\
\text { Management Education }\end{array}$ & 1 & 2 & UK & & $\begin{array}{l}\text { Student feedback on initiatives to integrating } \\
\text { sustainability is important. }\end{array}$ \\
\hline Wersun, 2017 & $\begin{array}{l}\text { International Journal of } \\
\text { Management Education }\end{array}$ & 1 & $4 / 5$ & UK & various & $\begin{array}{l}\text { Top down commitment is important; responsible } \\
\text { management education built into institutional } \\
\text { strategy. }\end{array}$ \\
\hline Wiek et.al.,2014 & $\begin{array}{l}\text { International Journal of } \\
\text { Sustainability in Higher } \\
\text { Education }\end{array}$ & NA & $2 / 4$ & USA & business & $\begin{array}{l}\text { Problem- and project-based learning module; the } \\
\text { challenge is how to maintain the institutional } \\
\text { momentum. }\end{array}$ \\
\hline
\end{tabular}




\begin{tabular}{|l|l|l|l|l|l|l|}
\hline Wong et.al., 2016 & The CPA Journal & NA & 2 & USA & Accounting. & $\begin{array}{l}\text { Of the more than 900 universities with } \\
\text { undergraduate or graduate accounting programs in } \\
\text { USA, only 17 list a course entirely } \\
\text { devoted to sustainability. }\end{array}$ \\
\hline
\end{tabular}




\section{References}

Akrivou, K. and Bradbury-Huang, H. (2015), "Educating integrated catalysts: transforming business schools toward ethics and sustainability", Academy of Management Learning \& Education, Vol. 14 No. 2, pp. 222-240.

Annan-Diab, F \& Molinari, C. (2017) Interdisciplinarity: Practical approach to advancing education for sustainability and for the Sustainable Development Goals, The International Journal of Management Education, Volume 15, Issue 2, Part B, pp. 7383.

Arruda Filho, N. d. P. (2017). The agenda 2030 for responsible management education: An applied methodology. International Journal of Management Education, 15(2B), 183191.

Awaysheh, A. \& Bonfiglio, D. (2017) Leveraging experiential learning to incorporate social entrepreneurship in MBA programs: A case study, The International Journal of Management Education, Volume 15, Issue 2, Part B, pp. 332-349.

Beddewela, E., Warin, C., Hesselden, F., \& Coslet, A. (2017). Embedding responsible management education - Staff, student and institutional perspectives. International Journal of Management Education, 15(2B), 263-279.

Bernstein, P. L. (2008). What Caused the Mess?. Journal of Portfolio Management, pp. 1-1.

Biggs, J. (2003) Teaching for quality learning at university (2nd Ed.). Berkshire, UK: Open University Press.

Bloom, R. (2013). Global Financial Crisis in Retrospect. CPA Journal, 83(3), 6-10.

Borges, J. C., Ferreira, T. C., Borges de Oliveira, M. S., Macini, N., \& Caldana, A. C. F. (2017). Hidden curriculum in student organizations: Learning, practice, socialization and responsible management in a business school. International Journal of Management Education, 15(2B), 153-161.

Burga, R., Leblanc, J., \& Rezania, D. (2017). Analysing the effects of teaching approach on engagement, satisfaction and future time perspective among students in a course on CSR. International Journal of Management Education, 15(2B), 306-317.

Carreira, F., Aguiar, A.C., Onça, F., \& Monzoni, M. (2017) The Celsius Game: An experiential activity on management education simulating the complex challenges for the two-degree climate change target, The International Journal of Management Education, Volume 15, Issue 2, Part B, pp.350-361.

Cicmil, S., Gough, G., Hills, S. (2017) Insights into responsible education for sustainable development: The case of UWE, Bristol, The International Journal of Management Education, Volume 15, Issue 2, Part B, 293-305.

Cornuel, E. (2007). Challenges facing business schools in the future. Journal of Management Development, 26(1), 87-92.

Cornuel, E., \& Hommel, U. (2015). Moving beyond the rhetoric of responsible management education. Journal of Management Development, 34(1), 2-15.

Coulson, A., \& Thomson, I. (2006). Accounting and sustainability, encouraging a dialogical approach; integrating learning activities, delivery mechanisms and assessment strategies. Accounting Education, 15(3), 261-273.

Godemann, J., Haertle, J., Herzig, C., \& Moon, J. (2014). United Nations supported Principles for Responsible Management Education: purpose, progress and prospects. Journal of Cleaner Production, 62, 16-23.

Gray, R. (2013). Sustainability + Accounting Education: The Elephant in the Classroom. Accounting Education, 22(4), 308-332.

Greenberg, D.N., Deets, S., Erzurumlu, S., Hunt, J., Manwaring, M. Rodgers, V., Swanson, E. (2017) Signing to living PRME: Learning from a journey towards responsible 
management education, The International Journal of Management Education, Volume 15, Issue 2, Part B, pp. 205-218.

Haski-Leventhal, D. (2014). MBA Student Values, Attitudes and Behaviors: A CrossCultural Comparison of PRME Signatory Schools. SAM Advanced Management Journal (07497075), 79(4), 29-41.

Hommel, U., Painter-Morland, M., \& Wang, J. (2012). Gradualism prevails \& perception outbids substance. Global Focus: The EFMD Business Magazine, 6(3), 30-33.

Kolb, M., Fröhlich, L., \& Schmidpeter, R. (2017). Implementing sustainability as the new normal: Responsible management education - From a private business school's perspective. International Journal of Management Education , 15(2B), 280-292.

Muff, K. (2012). Are business schools doing their job? Journal of Management Development, 31(7), 648-662.

Ortiz, D. \& Huber-Heim, K. (2017) From information to empowerment: Teaching sustainable business development by enabling an experiential and participatory problem-solving process in the classroom, The International Journal of Management Education, Volume 15, Issue 2, Part B, 318-331.

Painter-Morland, M., Sabet, E., Molthan-Hill, P., Goworek, H. and de Leeuw, S. (2016), "Beyond the curriculum: integrating sustainability into business schools", Journal of Business Ethics, Vol. 139 No. 4, pp. 737-754.

Rasche, A., Gilbert, D. U., \& Schedel, I. (2013). Cross-Disciplinary Ethics Education in MBA Programs: Rhetoric or Reality? In (Vol. 12, pp. 71-85): Academy of Management.

Rive, J., Bonnet, M., Parmentier, C., Pelazzo-Plat, V., Pignet-Fall, L. (2017) A contribution to the laying of foundations for dialogue between socially responsible management schools, The International Journal of Management Education, Volume 15, Issue 2, Part B, pp. 238-248.

Rusinko, C.A. (2010), "Integrating sustainability in management and business education”, Academy of Management Learning \& Education, Vol. 9 No. 3, pp. 507-519.

Sharma, R. R. (2017). A Competency Model for Management Education for Sustainability. Vision (09722629), 21(2), X-XV.

Tyran, K.L. (2017) Transforming students into global citizens: International service learning and PRME, The International Journal of Management Education, Volume 15, Issue 2, Part B, pp 162-171.

Wall, T. (2016a) Provocative Education: From Buddhism for Busy People ${ }^{\circledR}$ to Dismal Land ${ }^{\circledR}$, Studies in Philosophy and Education, March.

Wall, T. (2016b), “Žižekian ideas in critical reflection: the tricks and traps of mobilising radical management insight”, Journal of Work-Applied Management, Vol. 8 No. 1, pp. 5-16.

Wall, T. (2017) A manifesto for higher education, skills and work-based learning: through the lens of The Manifesto for Work, Higher Education, Skills and Work-Based Learning, 7 (3), 304-314.

Wall, T. (2018) Infusing ethics into leadership learning \& development, in Knights, J. et al (Ed.), Leading Beyond the Ego: How to Become a Transpersonal Leader, London, Routledge.

Wall, T. and Jarvis, M. (2015), "Business schools as educational provocateurs of productivity via interrelated landscapes of practice”, Chartered Association of Business Schools, London.

Wall, T. and Perrin, D. (2015), Slavoj Žižek: A Žižekian Gaze at Education, Springer, London. 
Wall, T., Bellamy, L., Evans, V., and Hopkins, S. (2017a) Revisiting impact in the context of workplace research: a review and possible directions, Journal of Work-Applied Management, 9 (2), pp.95-109.

Wall, T., Clough, D., Österlind, E., and Hindley, A. (2018, forthcoming). Conjuring A Spirit for Sustainability: a review of the socio-materialist effects of provocative pedagogies, in Leal Fihlo, W. (ed) Sustainability in Higher Education - World Sustainability Series, Springer.

Wall, T., Hindley, A., Hunt, T., Peach, J., Preston, M., Hartley, C., and Fairbank, A. (2017b). Work-based learning as a catalyst for sustainability: a review and prospects, Higher Education, Skills and Work-Based Learning, 7 (2), 211-224.

Wall, T., Tran, L.T. \& Soejatminah, S. (2017c). Inequalities and agencies in workplace learning experiences: international student perspectives, Vocations and Learning, 10 (2), pp 141-156.

Wall, T. and Hindley, A. (2018, forthcoming) Work integrated learning for sustainability education. In Leal et al (eds.), The Encyclopedia of Sustainability in Higher Education. Springer.

Wall, T. (2018, forthcoming) Service learning and sustainability education. In Leal et al (eds.), The Encyclopedia of Sustainability in Higher Education. Springer.

Wallison, P. J. (2011). Three narratives about the financial crisis. CATO Journal, 31(3), 535549.

Warwick, P., Wyness, L., \& Conway, H. (2017). 'Think of the future': Managing educational change from students' perspectives of an undergraduate sustainable business programme. International Journal of Management Education , 15(2B), 192-204.

Wersun, A. (2017) Context and the institutionalisation of PRME: The case of the University for the Common Good, The International Journal of Management Education, Volume 15, Issue 2, Part B, pp. 249-262.

Wong, J., Pippin, S., Weber, J., \& Bergner, J. (2016). The Inclusion of Sustainability in the Accounting Curriculum. CPA Journal, 86(6), 64-67. 